\author{
DOMINIKA KUŹNICKA-BŁASZKOWSKA \\ ORCID: 0000-0001-8804-569X \\ Uniwersytet Wrocławski
}

\title{
PRAWNA OCHRONA ŻYCIA PRYWATNEGO A OCHRONA INFORMACJI O SOBIE SAMYM W KONSTYTUCJI RP W ORZECZNICTWIE TRYBUNAŁU KONSTYTUCYJNEGO - WYBRANE ASPEKTY
}

\begin{abstract}
Abstrakt: Zagwarantowanie prawidłowych mechanizmów ochrony prywatności i informacji o sobie samym jest jednym z największych wyzwań stojących obecnie przed ustawodawcą. Jest to szczególnie trudne zadanie ze względu na różne koncepcje na temat prywatności, aspektów życia, które należy uznać za intymne dla jednostki, oraz pytanie, gdzie leży granica pomiędzy ochroną prywatności a autonomią informacyjną. Praktyka stosowania prawa w tym wypadku znacznie odbiega od rzeczywistości, o czym można się przekonać, analizując orzeczenia Trybunału Konstytucyjnego. Kwestia ta nabiera wyjątkowego znaczenia, kiedy prawo do prywatności bądź to dotyczy szczególnie wrażliwych dla jednostki informacji, bądź stoi w kontrze do innych dóbr prawnie chronionych. $\mathrm{Z}$ tego względu za zasadne uznałam przyjrzenie się bliżej orzecznictwu Trybunału Konstytucyjnego w zakresie ochrony prywatności i autonomii informacyjnej jednostki w kontekście informacji o jej stanie zdrowia, ochrony bezpieczeństwa i porządku publicznego, jak również jawności działania organów władzy publicznej.
\end{abstract}

Słowa kluczowe: prywatność, ochrona danych osobowych, inwigilacja, Trybunał Konstytucyjny, RODO

Zagwarantowanie prawidłowych mechanizmów ochrony prywatności i informacji o sobie samym jest jednym z największych wyzwań, jakie stoją obecnie przed ustawodawcą. Jest to szczególnie trudne zadanie ze względu na różnorodność koncepcji, czym jest prywatność, jakie aspekty życia należy uznać za intymne dla jednostki oraz gdzie leży granica pomiędzy ochroną prywatności a autonomią informacyjną. Polski ustrojodawca w Konstytucji RP poświęcił tym kwestiom aż dwie niezależne od siebie jednostki redakcyjne, sankcjonując tym samym obowiązki nałożone na Rzeczpospolitą przez prawo międzynarodowe. Mimo szerokich gwarancji konstytucyjnych praktyka pokazuje, jak różne może być rozumienie zarówno prywatności, jak i autonomii informacyjnej jednostki i jakie mogą być tego konsekwencje. Olbrzymią rolę w procesie odczytywania 
intencji ustrojodawcy odgrywa Trybunał Konstytucyjny, który przez lata nie tylko próbował tłumaczyć zawiłości art. 47 i 51 Konstytucji, lecz — co szczególnie ważne - odnosił się do najbardziej istotnych aspektów gwarancji w nich zawartych. Kwestia ta nabiera wyjątkowego znaczenia, kiedy prawo do prywatności bądź to dotyczy szczególnie wrażliwych dla jednostki informacji, bądź stoi w kontrze do innych dóbr prawnie chronionych. Biorąc pod uwagę obecne nastroje społeczne, strach przed działaniami terrorystycznymi i rozwój cyberprzestępczości, łatwiej bowiem zaakceptować ingerencję w prawo do prywatności ze strony organów publicznych. W takiej sytuacji zadaniem organów stosujących prawo, przede wszystkim sądów i trybunałów, jest zarówno zagwarantowanie poszanowania prawa i wolności jednostki, jak i ochrona innych dóbr prawnych. $Z$ tego względu za zasadne uznałam przyjrzenie się bliżej orzecznictwu Trybunału Konstytucyjnego w zakresie ochrony prywatności i autonomii informacyjnej jednostki w kontekście informacji o jej stanie zdrowia, ochrony bezpieczeństwa i porządku publicznego oraz jawności działania organów władzy publicznej.

\section{OCHRONA PRYWATNOŚCI I INFORMACJI O SOBIE SAMYM W KONSTYTUCJI RP}

Ochrona prywatności na gruncie ustawy zasadniczej stanowi pewne novum w polskim porządku prawnym ${ }^{1}$. Poprzednie uregulowania konstytucyjne odnosiły

1 Jednocześnie koniecznie należy wspomnieć, że zgodnie z art. 9 Rzeczpospolita jest związana obowiązkami pozytywnymi i negatywnymi dotyczącymi ochrony prywatności na gruncie prawa międzynarodowego. Ich podstawą jest między innymi art. 12 Powszechnej Deklaracji Praw Człowieka, art. 17 Międzynarodowego Paktu Praw Obywatelskich i Politycznych, art. 8 Europejskiej Konwencji Praw Człowieka czy art. 7 Karty Praw Podstawowych. Zob. W. Czapliński, A. Wyrozumska, Prawo międzynarodowe publiczne. Zagadnienia systemowe, Warszawa 2014, s. 102; J.P. Humphrey, The International Bill of Rights: Scope and Implementation, 17 Wm. \& Mary L. Rev. 527 (1976), http:// scholarship.law.wm.edu/wmlr/vol17/iss3/6, s. 530; postanowienie Sądu Najwyższego z 11 stycznia 2000 r., sygn. akt I PKN 562/99; P. Litwiński, Wprowadzenie, [w:] Rozporządzenie UE w sprawie ochrony osób fizycznych $w$ zwiazku z przetwarzaniem danych osobowych i swobodnym przeplywem takich danych. Komentarz, red. P. Litwiński, P. Barta, M. Kawecki, Warszawa 2018, s. 22. Ze względu na tematykę niniejszego artykułu oraz obszerne opracowania związane z RODO dalsze rozważania na ten temat zostaną pominięte; więcej na temat ochrony prywatności i danych osobowych w RODO zob. E.R. Alo, EU Privacy Protection: A Step towards Global Privacy, 22 Mich. St. Int'l L. Rev. 1095 (2014); A. Dmochowska, M. Zadrożny, Unijna reforma przepisów ochrony danych osobowych - analiza zmian, Warszawa 2016; D. Dyjak, Zasady podstawowe przetwarzania danych osobowych w świetle RODO, [w:] Reforma ochrony danych osobowych a jawność dostęu do informacji sądowej - aspekty proceduralne, red. M. Jabłoński, K. Flaga-Gieruszyńska, K. Wygoda, Wrocław 2017; A. Gonschior, Ochrona danych osobowych a prawo do prywatności w Unii Europejskiej, [w:] Aktualne problemy prawa Unii Europejskiej i prawa międzynarodowego. Aspekty teoretyczne i praktyczne, red. D. Kornobis-Romanowska, Wrocław 2017; M. Jabłoński, J. Węgrzyn, Zmiana modelu ochrony danych osobowych — podejście oparte na ryzyku, privacy by design $i$ privacy by default, [w:] Reforma ochrony danych...; A. Mednis, Reforma europejskich 
się co prawda do pewnych aspektów autonomii jednostki, jednak nigdy expressis verbis nie przyznawały jednostce ochrony prawa do prywatności. Jedyną kwestią uregulowaną we wszystkich nowożytnych konstytucjach w Rzeczypospolitej była tajemnica korespondencji rozbudowana następnie w Konstytucji PRL o nienaruszalność mieszkania².

Jeszcze przed wejściem w życie obecnie obowiązującej konstytucji pojawiały się wątpliwości, czy prawo do prywatności bądź też prywatność jako samoistna wartość powinny zostać objęte ochroną prawną ${ }^{3}$. Prywatność rozumiano przede wszystkim jako wartość odnoszącą się do życia rodzinnego jednostki, a także obejmującą fakty o najbardziej intymnych przymiotach jednostki, takich jak życie seksualne, stan zdrowia, przeszłość ${ }^{4}$. Jednocześnie już wtedy polskie sądy uznawały, że pewne elementy charakterystyczne jedynie dla konkretnej jednostki, jak na przykład głos, znajdują się pod ochroną prawną ${ }^{5}$.

W trakcie prac legislacyjnych nad konstytucją idea przyznania w ustawie zasadniczej prawa do „ochrony prawnej życia prywatnego, rodzinnego, czci i dobrego imienia" pojawiła się dosyć wcześnie (już w 1994 roku) ${ }^{6}$. Jednocześnie w pierwotnym założeniu komentowany przepis miał uwzględniać nie tylko ochronę prawa do prywatności, lecz również gwarantować jednostce autonomię informacyjną ${ }^{7}$, która ostatecznie została uregulowana w art. 51 Konstytucji.

W brzmieniu obecnie obowiązującym zasada wyrażona w art. 47 stanowi punkt wyjścia całego zespołu gwarancji konstytucyjnych. Jednocześnie art. 47 Konstytucji ustanawia niezwykle pojemną normę konstytucyjną — wydaje się,

regulacji prawnych dotyczacych ochrony danych osobowych - najważniejsze kierunki proponowanych zmian, „Informacja w Administracji Publicznej” 2015, nr 1; Z. Mielnik, Prawo do prywatności (zagadnienia wybrane), „Ruch Prawniczy, Ekonomiczny i Socjologiczny” 1996, nr 2; Privacy Rights in the Digital Age A Proposal for a New General Comment on the Right to Privacy under Article 17 of the International Covenant on Civil and Political Rights: A Draft Report and General Comment by the American Civil Liberties Union, https://www.aclu.org/sites/default/files/assets/jus14-report-iccpr-web-rel1.pdf (dostęp: 31.12.2018); O. Diggelmann, M.N. Cleis, How the right to privacy become a human right, „Human Rights Law Review” 14, 2014, nr 3, s. 441-458, https://doi. org/10.1093/hrlr/ngu014 (dostęp: 17.12.2018) — Komentarz Generalny Komitetu Praw Człowieka nr 16.

2 Transformacja ustrojowa charakteryzowała się między innymi zapewnieniem gwarancji przestrzegania uniwersalnych praw i wolności określonych w prawie międzynarodowym poprzez ich bezpośrednią implementację do polskiego porządku prawnego. Konsekwencją tego działania w zakresie ochrony prawa do prywatności i ochrony danych osobowych było przyjęcie w Konstytucji Rzeczpospolitej Polskiej odpowiednich norm, które mają za zadanie zapewnienie poszanowania tego prawa przez organy władzy publicznej.

${ }^{3}$ K.W. Kubiński, Ochrona życia prywatnego człowieka, „Ruch Prawniczy, Ekonomiczny i Socjologiczny" 1993, nr 1, s. 65.

4 Ibidem.

5 Wyrok Sądu Administracyjnego w Gdańsku z 21 czerwca 1991 roku, sygn. akt I ACr 127/91.

${ }^{6}$ M. Wild, Komentarz do art. 47 Konstytucji, [w:] Konstytucja RP. Komentarz, t. 1, red. M. Safjan, L. Bosek, Warszawa 2016, s. 1164.

7 Ibidem. 
że poszczególne interesy w nim wskazane, takie jak ,prawo do ochrony prawnej życia prywatnego”, ,prawo do ochrony prawnej życia rodzinnego”, „prawo do ochrony prawnej czci i dobrego imienia" wraz z prawem do samostanowienia, wyrażają samodzielne treści normatywne ${ }^{8}$. Przyjęcie, że art. 47 Konstytucji RP ustanawia normę ogólną, prowadzi do wniosku, że w przypadkach, w jakich ochrona prywatności nie jest realizowana przez regulacje szczególne, możliwe jest odwołanie się do zasady ogólnej wyrażonej w omawianym przepisie. Artykuł 47 Konstytucji zawiera w sobie co najmniej dwa istotne aspekty. Z jednej strony wynika z niego obowiązek władzy państwowej do uregulowania w drodze przepisów prawnych typu „ochronnego" zagadnień związanych z życiem prywatnym, rodzinnym innych dóbr określonych w komentowanym artykule ${ }^{9}$. Jednocześnie prawo nim stanowione ma charakter wolnościowy, polega bowiem na wykluczeniu wszelkiej postronnej ingerencji w sferę życia osobistego jednostki, zwłaszcza gdy może ona wpłynąć na podejmowanie przez jednostkę decyzji ${ }^{10}$. Oznacza to swobodę działania jednostek $w$ ramach wolności aż do granic ustanowionych w ustawie - jedynie wprowadzenie jednoznacznej regulacji ustawowej może nakładać ograniczenia w zakresie podejmowania określonych zachowań mieszczących się w ramach konkretnej wolności, jednocześnie nie jest dopuszczalne domniemanie kompetencji władz publicznych w zakresie ingerencji ${ }^{11}$.

Analizując konstytucyjne regulacje związane $\mathrm{z}$ ochroną prawa do prywatności, nie sposób pominąc innych norm prawnych wynikających z przepisów Konstytucji. I tak w art. 45 ust. 2 wskazano, że ochrona życia prywatnego jest jedną z przesłanek uzasadniających wyłączenie jawności rozprawy, w art. 76 zaś zawarto obowiązek zapewnienia konsumentom, użytkownikom i najemcom ustawowej ochrony przed działaniami zagrażającymi ich prywatności. Co więcej, trzeba również wskazać, że art. 47 jest wymieniony w art. 233 ust. 1 Konstytucji wśród przepisów, które nie mogą podlegać ograniczeniu w czasie stanu wojennego i wyjątkowego. Przyjęte w art. 233 określenie prywatności jako „dobra osobistego" wskazuje na ścisły związek tego przepisu z gałęzią prawa prywatnego ${ }^{12}$. Tak zredagowany przepis art. 233 ust. 1 potwierdza szczególną doniosłość prawa do prywatności - oznacza to, że nawet warunki wyjątkowe i ekstremalne nie zezwalają ustawodawcy na złagodzenie przesłanek, po spełnieniu których można wkroczyć w sferę życia prywatnego, nie narażając się na zarzut niekonstytucyjnej arbitralności ${ }^{13}$.

8 Ibidem, s. 1162.

9 P. Sarnacki, Komentarz do art. 47 Konstytucji, [w:] Konstytucja Rzeczpospolitej Polskiej. Komentarz, t. 2, red. L. Garlicki, M. Zubik, Warszawa 2016, s. 248.

10 Ibidem, s. 249.

11 Wyrok Trybunału Konstytucyjnego z 30 lipca 2014 roku, sygn. akt K 23/11.

12 M. Wild, op. cit., s. 1162.

13 Wyrok Trybunału Konstytucyjnego z 20 listopada 2002 roku, sygn. akt K 41/02. 
Samo pojęcie prywatności osoby fizycznej (i gwarantowanej jej konstytucyjnie ochrony prawa do prywatności) jest szersze od ochrony danych osobowych, która ma na celu zagwarantowanie jedynie pewnych jej aspektów ${ }^{14}$. Należy jednak wskazać, że część autorów uważa, że normy ogólnej konstytucyjnego prawa do prywatności powinno się poszukiwać raczej w gwarancji autonomii jednostki, to jest $\mathrm{w}$ art. $51^{15}$. Do takich wniosków w swoich rozważaniach dochodzi również Trybunał Konstytucyjny — według niego prywatność, o której mowa w art. 47 Konstytucji, „odnosi się między innymi do ochrony informacji dotyczących danej osoby i gwarancji pewnego stanu niezależności, w ramach której człowiek może decydować o zakresie i zasięgu udostępniania i komunikowania innym osobom informacji o swoim życiu"16. Prawo do prywatności należy rozumieć jako prawo do zachowania $\mathrm{w}$ tajemnicy informacji o swoim życiu prywatnym i odnosić do sfery autonomii informacyjnej jednostki ${ }^{17}$.

Współcześnie wydaje się, że biorąc pod uwagę rozwój technologiczny i zmiany społeczne w ostatnich latach, można wyciągnąć wniosek, że znacznie częściej mamy do czynienia z kreowaniem swoistego pozoru autonomii informacyjnej, ponieważ jednostka ma coraz mniejszy wspływ na zakres udostępnianej o sobie informacji ${ }^{18}$. Zadania $\mathrm{w}$ zakresie ochrony jednostki i jej prywatności niejednokrotnie podejmowane są przez instytucje publicznoprawne - wyznaczanie granic w tym zakresie dokonuje się nie przez prawo prywatne, lecz przez określenie granic obszaru chronionego w samym prawie publicznym, co w konsekwencji zawęża zakres autonomii jednostki ${ }^{19}$. Związane jest to przede wszystkim $\mathrm{z}$ tym, że osoba fizyczna $\mathrm{w}$ starciu $\mathrm{z}$ korporacyjnymi gigantami nie jest $\mathrm{w}$ stanie samodzielnie w pełni chronić swoich praw. Również Trybunał Konstytucyjny wskazuje, że to właśnie szerokie uprawnienia władz publicznych w zakresie ingerencji w prawo do prywatności jednostki stanowiły przesłankę wyodrębnienia prawa do ochrony autonomii informacyjnej jednostki z zakresu szeroko określonego prawa do prywatności ustanowionego w Konstytucji w art. 47. Autonomia informacyjna jednostki, której wyodrębnienie normatywne z całości ochrony prywatności przewiduje art. 51, jest uzasadniona częstotliwością, uporczywością i typowością wkraczania w prywatność przez władzę publiczną ${ }^{20}$. Co więcej, odróżnienie ochrony autonomii informacyjnej jednostki od pojęcia ochrony prywatności ułatwia ewentualne dostrzeżenie nadmiernej ingerencji i upraszcza udowodnienie, że takie wykroczenie nastąpiło.

\footnotetext{
14 Wyrok Trybunału Konstytucyjnego z 19 maja 1998 roku, sygn. akt U 5/97.

15 M. Wild, op. cit., s. 1162.

16 Wyrok Trybunału Konstytucyjnego z 19 maja 1998 roku.

17 Wyrok Trybunału Konstytucyjnego z 13 grudnia 2011 roku, sygn. akt K 33/08.

18 M. Safjan, Prawo do prywatności i ochrona danych osobowych w społeczeństwie informatycznym, „Państwo i Prawo” 2002, nr 6, s. 5.

19 Ibidem.

20 Wyrok Trybunału Konstytucyjnego z 13 grudnia 2011 roku, sygn. akt K 41/02.
} 
Ochrona prywatności i autonomia informacyjna jednostki nie mają charakteru absolutnego, a to ze względu między innymi na prawa i wolności innych jednostek czy potrzeby życia w zbiorowości. Jest to zresztą cecha wszystkich konstytucyjnych praw i wolności. Wszelkie ingerencje w prywatność muszą jednak mieć na uwadze jej ochronę jako dobra konstytucyjnie chronionego i zasady konstytucyjne wskazujące na granice i przesłanki, jakie muszą być zachowane na wypadek ingerencji. Obowiązek ujawnienia informacji o sobie, stanowiąc ograniczenie autonomii informacyjnej, może być zatem dokonany tylko w ustawie i tylko w granicach zgodnych z konstytucyjną zasadą proporcjonalności zgodnie z art. 31 Konstytucji.

Sfera prywatna jest zbudowana z różnych kręgów w mniejszym lub większym stopniu otwartych (prawnie) na oddziaływanie zewnętrzne i konstytucyjna aprobata dla władczego wkroczenia przez władzę nie jest jednakowa ${ }^{21}$. Prawo do prywatności i prawo ochrony danych osobowych wciąż pozostaje w bliskiej relacji, mimo że każde z nich ma charakter samoistny, bez wątpienia jednak jedną z funkcji ochrony danych osobowych jest zabezpieczenie prywatności informacyjnej jednostki ${ }^{22}$. Stąd też konieczność rozpatrywania dopuszczalnej ingerencji w prawo do prywatności w różnych aspektach, takich jak między innymi ochrona informacji o stanie zdrowia, uprawnienia służb specjalnych w działalności operacyjnej czy zbieg prawa do jawności życia publicznego i prawa do prywatności osób pełniących funkcje publiczne.

\section{INFORMACJE O STANIE ZDROWIA}

Informacje o stanie zdrowia są szczególną kategorią informacji dotyczących jednostki, wkraczającą w sferę jej prywatności i intymności. Zauważył to Europejski Trybunał Praw Człowieka ${ }^{23}$, który orzekł, że ochrona danych medycznych ma fundamentalne znaczenie dla możliwości korzystania przez jednostkę z prawa do poszanowania życia prywatnego i rodzinnego. Zdaniem ETPCz zapewnienie poufności danych medycznych jest zasadnicze nie tylko dla poszanowania poczucia prywatności pacjenta, lecz także dla zachowania jego zaufania do lekarzy oraz do usług ochrony zdrowia.

Podobny pogląd wyraża Trybunał Konstytucyjny, wskazując, że w sferze życia osobistego jednostki mieści się również prawo do decydowania o ochronie własnego życia i zdrowia ${ }^{24}$. Trybunał zauważył również, że obecność osoby trzeciej w trakcie udzielania świadczeń zdrowotnych ingeruje w prawo do pry-

21 Wyrok Trybunału Konstytucyjnego z 12 grudnia 2005 roku, sygn. akt K 32/04.

${ }^{22}$ M. Sakowska-Baryła, Dostęp do informacji publicznej a ochrona danych osobowych, Wrocław 2014, s. 33.

23 Wyrok Europejskiego Trybunału Praw Człowieka z 17 lipca 2008 roku w sprawie I. przeciwko Finlandii, skarga nr 20511/03.

24 Wyrok Trybunału Konstytucyjnego z 9 lipca 2009 roku, sygn. akt SK 48/05. 
watności ${ }^{25}$. Ma to zastosowanie także w stosunku do osób, które na podstawie zasad ogólnych są zobowiązane do zachowania tajemnic związanych z pełnioną przez nie służbą (nie mogą zatem ujawniać informacji na temat zdrowia badanego uzyskanych w trakcie obecności podczas udzielania świadczeń zdrowotnych) pacjent może czuć się skrępowany obecnością osoby trzeciej. Trybunał słusznie zauważył, że w czasie badania konieczne może być okazanie lekarzowi swojego ciała oraz ujawnienie informacji intymnych związanych z leczeniem, a obecność osoby trzeciej nie służy również ustanowieniu właściwej relacji pomiędzy lekarzem a pacjentem. Jednocześnie Trybunał zauważa, że w określonych wypadkach obecność osoby trzeciej, na przykład funkcjonariusza Straży Więziennej podczas badań medycznych skazanego, może przyczynić się do zapobieżenia czynowi bezprawnemu skazanego, a w wypadku takich czynów pozwala na szybką reakcję funkcjonariusza więziennego. Trybunał wskazuje, że nawet w specyficznych wypadkach — jakim jest przebywanie jednostki w zakładzie karnym — nie jest dopuszczalne wypreparowanie prywatności więźnia z wszelkiej treści, a do obszarów, które wciąż podlegają konstytucyjnej ochronie prawa do prywatności, należy opieka zdrowotna i potrzeba zapewnienia podczas jej świadczenia należytej poufności zawsze tam, gdzie jest to możliwe.

W podobnym tonie wypowiadał się Trybunał Konstytucyjny w sprawie dotyczącej konstytucyjności przepisów rozporządzenia Ministra Sprawiedliwości z dnia 23 lutego 2005 roku w sprawie poddawania badaniom lub wykonywania czynności z udziałem oskarżonego oraz osoby podejrzanej ${ }^{26}$. Trybunał podkreślał, że poszanowanie prywatności jest ściśle powiązane z ochroną godności ludzkiej, ponieważ zachowanie przez człowieka godności wymaga poszanowania sfery czysto osobistej jednostki ${ }^{27}$. Jest to nierozerwalnie związane $\mathrm{z}$ nienarażaniem jednostki na konieczność „bycia z innymi” czy „dzielenia się z innymi” swoimi przeżyciami czy doznaniami o intymnym charakterze. W ramach tej sfery prawa do prywatności zdaniem Trybunału Konstytucyjnego mieści się również prawo do poszanowania godności w trakcie zabiegów, które mają charakter medyczny i mogą wiązać się z ingerencją w organizm człowieka. Naruszeniem tej części intymności człowieka może być przymusowa obecność osoby trzeciej podczas takich zabiegów.

Nieco inaczej Trybunał Konstytucyjny wypowiadał się w wyroku K 25/1328 dotyczącym stwierdzenia zgodności z konstytucją przepisów ustawy transplan-

25 Wyrok Trybunału Konstytucyjnego z 26 lutego 2014 roku, sygn. akt 22/10.

${ }^{26}$ Rozporządzenie Ministra Sprawiedliwości z 23 lutego 2005 roku w sprawie poddawania badaniom lub wykonywania czynności z udziałem oskarżonego oraz osoby podejrzanej (Dz.U. Nr 33, poz. 299).

27 Wyrok Trybunału Konstytucyjnego z dnia 5 marca 2013 roku, sygn. akt U 2/11.

28 Wyrok Trybunału Konstytucyjnego z dnia 22 lipca 2014 roku, sygn. akt K 25/13. 
tacyjnej29. Zaskarżone przepisy dotyczyły gromadzenia i przetwarzania danych dawców. W uzasadnieniu Trybunał wskazał, że gromadzenie, przetwarzanie i udostępnianie danych o dawcach w rejestrze ogranicza ich prawo do prywatności i autonomii informacyjnej. Podkreślono również, że w wypadku takich rejestrów istotny jest adekwatny stopień zakresu zbieranych danych.

Dawców bowiem można opisać różnymi cechami, które niekoniecznie muszą mieć znaczenie dla prawidłowego funkcjonowania procesu doboru. Co istotne, nie działa w tym wypadku zasada, że „im więcej danych, tym lepiej”. Gromadzenie w rejestrze zbędnych informacji nie jest obojętne nie tylko dla prawa do prywatności i autonomii informacyjnej dawców, lecz także dla samego rejestru, bo zwiększa koszty jego obsługi i wydłuża czas jego przeszukiwania. Konieczne jest więc dokonanie bardziej szczegółowej analizy. Na podstawie ustawy transplantacyjnej należy stwierdzić, że pod względem merytorycznym rejestr powinien zawierać dane, które co najmniej pozwalają jednoznacznie ustalić tożsamość osoby zarejestrowanej i umożliwiają ocenę, czy w ogóle może ona być dawcą macierzystych komórek krwiotwórczych (abstrakcyjne) oraz jej przynajmniej wstępne dopasowanie do konkretnego dawcy (osoby oczekującej na przeszczep), tak aby ocenić, czy jest sens wykonywać dalsze, bardziej szczegółowe badania ${ }^{30}$.

Wynika z tego, że naruszeniem art. 51 i 47 Konstytucji byłoby pozyskiwanie danych, których zakres wykracza poza zakres niezbędny do prawidłowego funkcjonowania rejestru, czyli danych, które są nieodzowne do określenia zgodności dawcy z osobą oczekującą na transplantację. Jednocześnie, jak zauważył Trybunał, konieczne jest zagwarantowanie na szczeblu ustawowym prawidłowego przetwarzania danych, $w$ tym ich przekazywania do podmiotów trzecich (również publicznych) bez jakichkolwiek ograniczeń przedmiotowych, czasowych i proceduralnych. Ważne jest także zamieszczenie $\mathrm{w}$ ustawie regulującej przetwarzanie określonych kategorii danych przepisów kompetencyjnych stanowiących podstawę przekazywania danych pomiędzy organami władzy publicznej bądź pomiędzy podmiotami publicznymi a prywatnymi. Również Europejski Trybunał Praw Człowieka wskazywał w postępowaniu toczącym się przeciwko Polsce, że obowiązkiem państwa jest zapewnienie w prawie krajowym środków ochrony prawnej przed arbitralnymi ingerencjami władz publicznych w prawa zagwarantowane w Europejskiej Konwencji Praw Człowieka ${ }^{31}$.

Organy władzy publicznej oraz podmioty wykonujące zadania publiczne mogą przetwarzać dane osobowe, lecz jedynie w granicach określonych w ustawie oraz zachowując proporcjonalność pomiędzy zakresem przetwarzanych danych a celem, do którego są one wykorzystywane. Jednocześnie to stanowisko Trybunału nie ma odzwierciedlenia w sytuacji przetwarzania danych osobowych i ingerencji w prywatność jednostki podejmowanych przez organy ścigania.

29 Ustawa z 1 lipca 2005 roku o pobieraniu, przechowywaniu i przeszczepianiu komórek, tkanek i narządów (tekst jedn. Dz.U. z 2017 r. poz. 1000 ze zm.).

30 Wyrok Trybunału Konstytucyjnego z dnia 22 lipca 2014 roku.

31 Wyrok Europejskiego Trybunału Praw Człowieka z 26 maja 2011 roku w sprawie R.R. przeciwko Polsce, skarga 27617/04. 


\section{UPRAWNIENIA SŁUŻB SPECJALNYCH}

Przyznanie pewnym uprawnionym podmiotom określonych środków służących szeroko pojętej ochronie dóbr jest jedną z metod zapewnienia ochrony wolności i praw jednostki przez władze publiczne w demokratycznym państwie prawnym $^{32}$. Obowiązek państwa $\mathrm{w}$ zakresie zapewnienia bezpieczeństwa obejmuje nie tylko zapewnienie bezpieczeństwa publicznego, lecz również wprowadzenie środków, dzięki którym jednostka swobodnie i nieniepokojona przez inne podmioty może korzystać z własnych uprawnień ${ }^{33}$. Naturalne jest, że członkowie społeczeństwa oczekują od państwa zapewnienia poczucia bezpieczeństwa, zagwarantowania ochrony interesów jednostek, zagwarantowania nietykalności osobistej, w tym bezpieczeństwa osobistego, lecz także pozostawienia w spokoju ich sfery życia prywatnego ${ }^{34}$. Jednocześnie zapewnienie bezpieczeństwa publicznego wiąże się często z koniecznością ograniczenia korzystania przez jednostkę z przynależnych jej praw. W dobie wysokiego zagrożenia działaniami terrorystycznymi i przestępczością zorganizowaną, a także wysoko rozwiniętych metod inwigilacji stosowanych przez służby specjalne szczególnie zagrożone jest prawo człowieka do prywatności.

Przepisy obowiązujące w Polsce od lutego 2016 roku (wprowadzone tak zwaną ustawą inwigilacyjną) $)^{35}$ przewidują uprawnienia policji i służb specjalnych do korzystania z danych telekomunikacyjnych. W Polsce źródłem metadanych telekomunikacyjnych są w tym momencie przede wszystkim bazy danych czterech największych operatorów telekomunikacyjnych. Służby za pomocą stałych łączy i specjalnych interfejsów mają dostęp do danych telekomunikacyjnych. Namierzanie jednej bądź kilku podejrzanych osób odbywa się nieraz dzięki pobraniu $i$ analizie informacji dotyczących wszystkich numerów, które w danym momencie łączyły się z konkretnymi stacjami BTS. Policja i służby w związku z pozyskiwaniem ogromu informacji z różnych źródeł (publicznie dostępnych) korzystają z narzędzi służących do analizy — na przykład LINK/MAMUT czy LINK2 ${ }^{36}$.

Policja i służby specjalne bez zgody sądu nie mają uprawnień do zapoznawania się z treścią komunikacji poprzez e-maile, SMS-y czy wiadomości wysyłane przez portale społecznościowe; dotyczy to również różnych materiałów, takich jak

32 M. Ławrynowicz-Mikłaszewicz, Bezpieczeństwo jako prawo człowieka w kontekście stosowania środków przymusu bezpośredniego i broni palnej przez uprawnione podmioty, „Przegląd Prawniczy, Ekonomiczny i Społeczny” 2014, nr 4, s. 64.

33 A. Siostrzonek-Sergiel, Prawo do prywatności a bezpieczeństwo publiczne realizowane przez proces karny, „Kultura Bezpieczeństwa. Nauka — Praktyka — Refleksje” 16, 2014, s. 401.

${ }^{34}$ M. Ławrynowicz-Mikłaszewicz, op. cit., s. 64.

35 Ustawa z 15 stycznia 2016 roku o zmianie ustawy o Policji oraz niektórych innych ustaw (Dz.U. z 2016 r. poz. 147).

${ }^{36}$ Fundacja Panoptykon, Zabawki Wielkiego Brata. Krótki przewodnik po narzędziach, które pomagaja państwu kontrolować obywateli, Warszawa 2016, s. 53, https://panoptykon.org/zabawki-wielkiego-brata (dostęp: 3.03.2019). 
dokumenty, zdjęcia, filmy. Służby specjalne mają zarazem dostęp do Remote Control System - platformy służącej do infekowania, a następnie zdalnego i ukrytego kontrolowania urządzeń, takich jakich komputery i telefony komórkowe. Przejęcie kontroli nad wybranym urządzeniem pozwala utrwalać wszystkie czynności jego użytkownika: oglądać odwiedzane przez niego strony, czytać przesyłaną pocztę, słuchać rozmów wykonywanych przez Skype'a, a nawet przechwytywać wpisywane hasła ${ }^{37}$.

W orzecznictwie Trybunału Konstytucyjnego zauważa się, że pewne czynności podejmowane przez organy ścigania i służby specjalne w warunkach kontroli operacyjnej są prowadzone w sposób dający organom ścigania duży margines uznaniowości przy ograniczonych gwarancjach dla praw osoby poddanej tym czynnościom $^{38}$. Jednocześnie Trybunał wskazuje, że ten sposób działania organów ścigania jest współcześnie konieczny, ponieważ nadmierna przejrzystość działania tych organów powodowałaby ich nieskuteczność, a co za tym idzie uniemożliwiłaby zapewnienie bezpieczeństwa obywateli i państwa w warunkach wzmożonego zagrożenia działaniami terrorystycznymi oraz cyberprzestępczością. Nie odmiennie jednak szerokie uprawnienia organów ścigania w zakresie działalności operacyjnej pozostają w naturalnym konflikcie z prawem jednostki do ochrony jej prywatności. Sytuację komplikuje to, że czynności operacyjno-rozpoznawcze mają charakter nieprocesowy, a w związku z tym sądowa kontrola nad ich przebiegiem jest ograniczona.

Jak już zauważono, środki pozostające $\mathrm{w}$ dyspozycji władz publicznych pozwalają na daleko idącą ingerencję w prawo do prywatności. Niezachowanie proporcjonalności pomiędzy ochroną interesu publicznego i prawa jednostki do prywatności może doprowadzić do przekreślenia istoty prawa do prywatności, a to mogłoby doprowadzić nawet do zagrożenia godności jednostki i de facto pozbawienia jej autonomii informacyjnej polegającej na ochronie każdej informacji osobowej i przyznaniu podstawowego znaczenia przesłance zgody osoby zainteresowanej na udostępnienie informacji ${ }^{39}$.

Środki stosowane przy kontroli operacyjnej mogą być uznane za usprawiedliwione, jeśli ich celem jest obrona wartości demokratycznego państwa prawnego. Nie jest wystarczająca zatem sama celowość, pożyteczności, taniość czy łatwość posługiwania się nimi przez organy administracji publicznej — powinny być one uznane za konieczne w demokratycznym państwie prawnym. Dozwolone może zostać jedynie zastosowanie środków niezbędnych (koniecznych) w tym sensie, że będą one chronić określone wartości w sposób bądź w stopniu, który nie mógłby być osiągnięty przy zastosowaniu innych środków, a jednocześnie powinny to

\footnotetext{
37 Ibidem.

38 Wyrok Trybunału Konstytucyjnego z 12 grudnia 2005 roku, sygn. akt K 32/04.

39 Wyrok Trybunału Konstytucyjnego z 20 czerwca 2005 roku, sygn. akt K 4/04.
} 
być środki jak najmniej uciążliwe dla podmiotów, których prawo bądź wolność ulegają ograniczeniu ${ }^{40}$.

Na marginesie należy zauważyć, że szerokie uprawnienia służb specjalnych w zakresie kontroli operacyjnej były wielokrotnie przedmiotem krytyki Komitetu Praw Człowieka ${ }^{41}$. Europejski Trybunał Praw Człowieka w swoim orzecznictwie podkreśla, że rozważając potrzebę ochrony bezpieczeństwa państwa i zwalczania terroryzmu, trzeba uwzględnić znaczenie oraz dolegliwości ingerencji w prawo do poszanowania życia prywatnego osób objętych tajną kontrolą ${ }^{42}$. Wydaje się, że istnieją podstawy do uznania, że Rzeczpospolita Polska nie realizuje w pełni postanowień Paktu ani Konwencji, czym narusza nie tylko przepisy MPOiP, ale również art. 9 Konstytucji w zakresie zobowiązania Polski do przestrzegania umów międzynarodowych, których Rzeczpospolita jest stroną.

40 Wyrok Trybunału Konstytucyjnego z 3 października 2000 roku, sygn. akt K 33/99.

41 Zob. realizacja przez Polskę Międzynarodowego Paktu Praw Obywatelskich i Politycznych. Raport złożony w Komitecie Praw Człowieka, Genewa 26 i 27 marca 1987 roku, https://www.bip. ms.gov.pl/Data/Files/_public/bip/prawa_czlowieka/onz/kss3_1987.pdf (dostęp: 17.12.2018); raport Komitetu Praw Człowieka z 1987 roku, https://tbinternet.ohchr.org/_layouts/treatybodyexternal/Download.aspx?symbolno=A\%2f42\%2f40\&Lang=en (dostęp: 17.12.2018); realizacja przez Polskę Międzynarodowego Paktu Praw Obywatelskich i Politycznych. raport złożony w Komitecie Praw Człowieka, Genewa 28 i 29 października 1991 roku, https://www.bip.ms.gov.pl/Data/ Files/_public/bip/prawa_czlowieka/onz/zal1991.pdf (dostęp: 17.12.2018); raport Komitetu Praw Człowieka z 1994 roku, https://tbinternet.ohchr.org/_layouts/treatybodyexternal/Download. aspx?symbolno=A\%2f47\%2f40(SUPP)\&Lang=en (dostęp: 17.12.2018); realizacja przez Polskę Międzynarodowego Paktu Praw Obywatelskich i Politycznych. Raport złożony w Komitecie Praw Człowieka, Warszawa 2005, https://www.bip.ms.gov.pl/Data/Files/_public/bip/prawa_czlowieka/onz/ms_publikacja.pdf (dostęp: 17.12.2018); uwagi końcowe Komitetu Praw Człowieka do VI sprawozdania okresowego Polski, https://www.google.com/search?ei=IHwWXIvnJ4rRwQLhxquYBA\&q=poland + period +6 th + report + human + rights + committee \&oq=poland + period +6 th + re port+human+rights+com\&gs_l=psy-ab.3.1.33i21j33i160.9290.10363..11841..1.0..0.272.1018. 0j3j2.....0....1..gws-wiz......0i71.97IMARrn5rE\# (dostęp: 16.12.2018); realizacja przez Polskę Postanowień Międzynarodowego Paktu Praw Obywatelskich i Politycznych, VI sprawozdanie okresowe Rzeczypospolitej Polskiej z realizacji postanowień Międzynarodowego Paktu Praw Politycznych i Obywatelskich obejmujące okres od 1 października 2003 roku do 15 października 2008 roku, https://bip.ms.gov.pl/pl/prawa-czlowieka/onz-i-prawa-czlowieka/konwencje/miedzynarodowy-pakt-praw-obywatelskich-i-politycznych/ (dostęp: 17.12.2018); zalecenia Komitetu Praw Człowieka ONZ z rozpatrzenia VII sprawozdania okresowego Polski z realizacji postanowień Międzynarodowego Paktu Praw Obywatelskich i Politycznych, https://www.rpo.gov.pl/pl/content/ ogloszenie-zalecen-komitetu-praw-czlowieka-onz-z-vii-sprawozdania-okresowego-polski (dostęp: 16.12.2018); uwagi końcowe Komitetu Praw Człowieka do VII sprawozdania okresowego Polski za lata 2008-2015, https://www.rpo.gov.pl/sites/default/files/CCPR_C_POL_CO_7_25815_E.pdf (dostęp: 16.12.2018); D. Kuźnicka-Błaszkowska, Rekomendacje w zakresie prawa do prywatności wydane przez Komitet Praw Człowieka i ich realizacja w Polsce, [w:] 70 lat Powszechnej Deklaracji Praw Człowieka ONZ, red. M. Florczak-Wątor, M. Kowalski, Kraków 2019, s. 91-106.

42 Wyrok Europejskiego Trybunału Praw Człowieka z 7 czerwca 2006 roku w sprawie Segerstedt-Wiber i inni przeciwko Szwecji, skarga nr 62332/00. 


\section{PRAWO DO PRYWATNOŚCI A DOSTĘP DO INFORMACJI PUBLICZNEJ}

Ochrona danych osobowych wydaje się wyspecjalizowaną postacią prawa do prywatności. Jednocześnie rozwój tej koncepcji zbiega się z rozwojem prawa do informacji, transparencji życia publicznego, swobody wyrażania własnych poglądów. Wydaje się, że niemożliwe jest pogodzenie interesów zwolenników obu koncepcji - wzmocnionej ochrony prywatności i danych osobowych oraz pełnej transparentności życia publicznego. Niezbędne zdaje się odpowiednie wyważenie obu dóbr i stworzenie takich przepisów prawnych, które w jak największym stopniu pozwolą zaspokoić podstawowe potrzeby przedstawicieli obu nurtów. Na część pytań związanych ze zbiegiem prawa do prywatności i zasady jawności życia publicznego starał się w swoim orzecznictwie odpowiedzieć Trybunał Konstytucyjny.

Bez wątpienia art. 47 Konstytucji RP stanowi, że każdy ma prawo do prawnej ochrony życia prywatnego oraz do decydowania o swoim życiu osobistym, jednak w odniesieniu do osób ubiegających się lub pełniących funkcje publiczne prawo do ochrony prywatności podlega istotnemu ograniczeniu. Wydaje się zatem, że osoba kandydująca do pełnienia funkcji publicznej musi się godzić z zainteresowaniem opinii publicznej związanej z uzyskaniem jak najszerszego zakresu informacji o jej życiu (również prywatnym) i przeszłości. O ile sfera życia intymnego (w znaczeniu szerszym niż potocznie przyjęte) jest objęta pełną prawną ochroną, o tyle ochrona sfery życia prywatnego podlega jednak pewnym ograniczeniom uzasadnionym „usprawiedliwionym zainteresowaniem”43.

W wyroku z 20 marca 2006 roku Trybunał Konstytucyjny wskazywał, że sfera chronionej prywatności pozostaje niejednokrotnie w związku z informacjami odnoszącymi się do działalności organów publicznych ${ }^{44}$. Trybunał zauważył, że tendencją charakterystyczną dla orzecznictwa i regulacji europejskich jest dążenie do zagwarantowania możliwie szerokiego dostępu do informacji publicznych, ponieważ stanowi to istotną gwarancję transparentności życia publicznego w demokratycznym państwie. Uznaje się w konsekwencji, że prywatność osób pełniących funkcje publiczne, pozostając pod ochroną gwarancji konwencyjnych (zwłaszcza art. $8 \mathrm{EKPCz}$ ), może podlegać ograniczeniom, które co do zasady mogą znajdować usprawiedliwienie ze względu na wartość, jaką jest jawność i dostępność informacji o funkcjonowaniu instytucji publicznych w państwie demokratycznym. Nie oznacza to jednak, że transparentność życia publicznego może prowadzić do przekreślenia i zanegowania ochrony związanej z życiem prywatnych osób wykonujących funkcje publiczne. Osoby takie z momentem podjęcia swoich zadań

43 Wyrok Trybunału Konstytucyjnego z 21 października 1998 roku, sygn. akt K 24/98.

44 Wyrok Trybunału Konstytucyjnego z 20 marca 2006 roku, sygn. akt K 17/05. 
muszą zaakceptować szerszy zakres ingerencji w sferę ich prywatności niż w wypadku innych osób.

Również sama ustawa o dostępie do informacji publicznej ${ }^{45} \mathrm{~W}$ art. 5 zawiera ograniczenia w dostępie do informacji publicznej ze względu na konieczność ochrony prywatności jednostki. Ograniczenie prawa dostępu do informacji ze względu na prywatność osoby fizycznej nie obejmuje informacji na temat osób pełniących funkcje publiczne, mające związek z pełnieniem tych funkcji, a także o warunkach powierzenia i wykonywania funkcji. Konieczne jest zachowanie równowagi pomiędzy prymatem jawności, która znacznie uzdrawia życie społeczne, a konstytucyjnym prawem jednostki do ochrony prywatności. Niezależnie od tego, czy dana osoba z powodu wykonywanego zawodu sprawuje funkcje publiczne, czy nie, powinna ona móc swobodnie korzystać ze swojej sfery prywatnej, a co więcej, może skutecznie domagać się od państwa ochrony przed jej naruszaniem ${ }^{46}$.

Przy rozstrzyganiu, która z zasad powinna przeważyć w konkretnym stanie prawnym, bierze się pod uwagę kryterium przedmiotowe i podmiotowe. Pierwsze z nich ma wskazać, jaki typ informacji powinien podlegać udostępnieniu w imię zapewnienia jawności życia publicznego, a drugie dotyczy podmiotu, którego życie prywatne podlega ochronie ${ }^{47}$.

Trybunał Konstytucyjny w orzeczeniu z 20 marca 2006 roku podkreślił, że istnieją informacje, które również w wypadku osób publicznych nie będą się mieścily w ramach zakresu przedmiotowego sfery prawa do informacji. Co do zasady zalicza się do nich dane dotyczące stanu zdrowia czy sfery intymności (na przykład życia seksualnego). Jednocześnie należy zaznaczyć, że gdy realizacja prawa do informacji publicznej wkracza w sferę pośrednią pomiędzy życiem publicznym a prywatnym, ocena dopuszczalności ingerencji polegającej na „odkrywaniu” tej sfery życia poprzez jej ujawnienie innym osobom powinna być dokonywana niezwykle ostrożnie i z wyważeniem racji, które mogłyby przemawiać za uznaniem priorytetu interesu publicznego wyrażającego się w konstytucyjnej gwarancji prawa do informacji w stosunku do ochrony prywatności. Trybunał zauważył,

45 Ustawa z 6 września 2001 roku o dostępie do informacji publicznej (Dz.U. z 2016 r. poz. 1764 ze zm.), dalej: u.d.i.p.

46 Zob. również wyrok Trybunału Konstytucyjnego z 21 października 1998 roku, sygn. akt K 24/98, w którym zauważono: „każdy ma prawo do prawnej ochrony życia prywatnego oraz do decydowania o swoim życiu osobistym. Jednocześnie jednak przeważa w doktrynie pogląd, w myśl którego, w odniesieniu do osób ubiegających się lub pełniących funkcje publiczne, prawo do ochrony prywatności podlega istotnemu ograniczeniu. Zgodnie z tym poglądem, o ile sfera życia intymnego (w znaczeniu szerszym niż potocznie przyjęte) objęta jest pełną prawną ochroną, o tyle ochrona sfery życia prywatnego podlega pewnym ograniczeniom, uzasadnionym usprawiedliwionym zainteresowaniem".

47 J. Karczewski, T. Stawecki, Prywatność i jawność — ważenie zasad prawnych, [w:] Prywatność a jawność — bilans 25-lecia i perspektywy na przyszłość, red. A. Mednis, Warszawa 2016, s. 144. 
że ingerencja w prawo do prywatności jest uzasadniona jedynie gdy informacje, których natura i charakter może naruszać interesy i prawa innych osób, nie wykraczają poza niezbędność określoną potrzebą transparentności życia publicznego, ocenianą zgodnie ze standardami przyjętymi w demokratycznym państwie. Muszą to być jednak zawsze informacje mające znaczenie dla oceny funkcjonowania instytucji oraz osób pełniących funkcje publiczne. Jednocześnie nie mogą to być informacje - co do swej natury i zakresu — przekreślające sens (istotę) ochrony prawa do życia prywatnego.

W konsekwencji, jak podkreślono w wyroku w sprawie K 41/0248, istnienie gwarancji i realizacja konstytucyjnego prawa do informacji nie może prowadzić do wniosku o wyłączeniu w wypadku osób publicznych ochrony innych praw, jakie wszystkim gwarantuje konstytucja, a których realizacja mogłaby kolidować z prawem do informacji. Dotyczy to przede wszystkim, choć nie tylko, gwarantowanej konstytucyjnie ochrony sfery prywatności.

$Z$ biegiem lat zagadnieniem zbiegu zasady jawności i prawa do ochrony prywatności zajmowały się przede wszystkim sądy administracyjne. Wskazywały one, że osoby pełniące funkcje publiczne nie mogą się skutecznie powołać na prawo do prywatności w wypadku wniosków o udostępnienie oświadczeń lustracyjnych, daty urodzenia, miejsca zamieszkania czy postępowań dyscyplinarnych ${ }^{49}$.

\section{PODSUMOWANIE}

W demokratycznym państwie prawnym w warunkach pokojowych wartości związane z ochroną praw i wolności jednostki ścierają się z dobrami chronionymi przed organy publiczne, takimi jak bezpieczeństwo i zdrowie publiczne, porządek publiczny czy po prostu ochrona interesów gospodarczych państwa. Rolą sądów i innych organów stosujących prawo jest taka interpretacja przepisów, która pozwala na pogodzenie z sobą często sprzecznych wartości. Jednocześnie ustawodawca nie powinien wprowadzać przepisów, które naruszają zasadę proporcjonalności i istotę chronionych praw i wolności.

W kontekście przeprowadzonych rozważań mogą pojawić się wątpliwości co do podstawy naruszonego prawa do ochrony prywatności bądź danych osobowych. Wydaje się, że skoro norma art. 47 Konstytucji jest normą-zasadą, to można się do niej odwołać każdorazowo, gdy naruszone zostaje bezpieczeństwo danych osobowych jednostki. Co więcej, co do zasady przepis art. 51 ma skutki przede

48 Wyrok Trybunału Konstytucyjnego z 20 marca 2006 roku, sygn. akt K 41/02.

49 D. Kuźnicka, Dostęp do informacji publicznej a ochrona prywatności w praktyce udostępniania informacji publicznej przez sądy, [w:] Reforma ochrony danych osobowych a jawność dostępu do informacji sądowej: aspekty proceduralne, red. M. Jabłoński, K. Flaga-Gieruszyńska, K. Wygoda, Wrocław 2017, s. 227-238, http://www.bibliotekacyfrowa.pl/publication/92803 (dostęp: 9.02.2019). 
wszystkim w relacjach pomiędzy jednostką a organami władzy publicznej, można zatem przyjąć, że w relacjach horyzontalnych podstawą dochodzenia konstytucyjnych praw będzie przepis art. 47. Na gruncie regulacji konstytucyjnych można stwierdzić, że prawo do ochrony danych osobowych jest rozwinięciem prawa człowieka do prywatności, jego bardziej uszczegółowioną formą.

Pomimo silnych gwarancji konstytucyjnych wciąż wydaje się, że w wielu wypadkach przepisy przyjmowane przez ustawodawcę nie chronią dostatecznie prawa do prywatności i ochrony danych osobowych jednostki. W dobie nowych technologii oraz coraz powszechniejszego zagrożenia cyberterroryzmem ustawodawca często większą wagę przykłada do kwestii bezpieczeństwa państwa niż bezpieczeństwa prywatności jednostki. Bez wątpienia ogólnoświatowy trend zakłada większy nacisk na kwestie związane z ochroną przed przestępczością, jednak wydaje się, że stosowane ograniczenia zbyt mocno ingerują w sferę prywatną jednostki. Działania ustawodawcy w tym zakresie znajdują odzwierciedlenie w orzecznictwie Trybunału Konstytucyjnego, który wskazuje, że w warunkach zagrożenia bezpieczeństwa państwa zasadne jest ograniczenie prawa do prywatności z zachowaniem odpowiedniej proporcjonalności podejmowanych działań. Odmienne podejście reprezentują Europejski Trybunał Praw Człowieka oraz Komitet Praw Człowieka, które podkreślają wagę i znaczenie bezpieczeństwa państwa i obywateli przed terroryzmem, jednocześnie wskazując na konieczność takiego ukształtowania przepisów krajowych, które zapewni jednostce ochronę przed bezprawną ingerencją organów państwa w jej prywatności.

\section{LEGAL PROTECTION OF ONE'S PRIVATE LIFE AND PROTECTION OF INFORMATION ABOUT ONESELF IN THE CONSTITUTION OF THE REPUBLIC OF POLAND IN THE CASE LAW OF THE CONSTITUTIONAL TRIBUNAL — SELECTED ASPECTS}

\section{Summary}

Guaranteeing proper mechanisms for protecting privacy and information about oneself is one of the biggest challenges currently facing the legislator. This is a particularly difficult task, given the various concepts about what privacy is, what aspects of life should be considered intimate for the individual, and where the border between the protection of privacy and information autonomy lies. The practice of applying the law in this case significantly differs from reality, which can be seen when analysing the rulings of the Constitutional Tribunal. This issue takes on a special meaning when the right to privacy either concerns particularly sensitive information for the individual or stands in opposition to other legally protected goods. For this reason, I considered it appropriate to take a closer look at the jurisprudence of the Constitutional Tribunal regarding the protection of privacy and informational autonomy of an individual in the context of information about his state of health, protection of security and public order, as well as the openness of public authorities.

Keywords: privacy, data protection, GDPR, Constitutional Tribunal, surveillance 


\section{BIBLIOGRAFIA}

Alo E.R., EU Privacy Protection: A Step towards Global Privacy, 22 Mich. St. Int'l L. Rev. 1095 (2014).

Banaszak B., Komentarz do art. 9 Konstytucji RP, [w:] idem, Konstytucja Rzeczypospolitej Polskiej. Komentarz, Warszawa 2012.

Czapliński W., Wyrozumska A., Prawo międzynarodowe publiczne. Zagadnienia systemowe, Warszawa 2014

Diggelmann O., Cleis M.N., How the right to privacy become a human right, „Human Rights Law Review" 14, 2014, nr 3.

Dmochowska A., Zadrożny M., Unijna reforma przepisów ochrony danych osobowych — analiza zmian, Warszawa 2016.

Dyjak D., Zasady podstawowe przetwarzania danych osobowych w świetle RODO, [w:] Reforma ochrony danych osobowych a jawność dostępu do informacji sądowej - aspekty proceduralne, red. M. Jabłoński, K. Flaga-Gieruszyńska, K. Wygoda, Wrocław 2017.

Fundacja Panoptykon, Zabawki Wielkiego Brata. Krótki przewodnik po narzędziach, które pomagaja państwu kontrolować obywateli, Warszawa 2016.

Gonschior A., Ochrona danych osobowych a prawo do prywatności w Unii Europejskiej, [w:] Aktualne problemy prawa Unii Europejskiej i prawa międzynarodowego. Aspekty teoretyczne i praktyczne, red. D. Kornobis-Romanowska, Wrocław 2017.

Humphrey J.P., The International Bill of Rights: Scope and Implementation, 17 Wm. \& Mary L. Rev. 527 (1976), http://scholarship.law.wm.edu/wmlr/vol17/iss3/6.

Jabłoński M., Węgrzyn J., Zmiana modelu ochrony danych osobowych — podejście oparte na ryzyku, privacy by design $i$ privacy by default, [w:] Reforma ochrony danych osobowych a jawność dostęu do informacji sądowej — aspekty proceduralne, red. M. Jabłoński, K. Flaga-Gieruszyńska, K. Wygoda, Wrocław 2017.

Karczewski J., Stawecki T., Prywatność i jawność - ważenie zasad prawnych, [w:] Prywatność a jawność - bilans 25-lecia i perspektywy na przyszłość, red. A. Mednis, Warszawa 2016.

Kubiński K.W., Ochrona życia prywatnego człowieka, „Ruch Prawniczy, Ekonomiczny i Socjologiczny" 1993, nr 1 .

Kuźnicka D., Dostęp do informacji publicznej a ochrona prywatności w praktyce udostępniania informacji publicznej przez sady, [w:] Reforma ochrony danych osobowych a jawność dostępu do informacji sądowej: aspekty proceduralne, red. M. Jabłoński, K. Flaga-Gieruszyńska, K. Wygoda, Wrocław 2017.

Kuźnicka-Błaszkowska D., Rekomendacje w zakresie prawa do prywatności wydane przez Komitet Praw Człowieka i ich realizacja w Polsce, [w:] 70 lat Powszechnej Deklaracji Praw Człowieka ONZ, red. M. Florczak-Wątor, M. Kowalski, Kraków 2019.

Litwiński P., Wprowadzenie, [w:] Rozporządzenie UE w sprawie ochrony osób fizycznych w zwiazku $z$ przetwarzaniem danych osobowych i swobodnym przeptywem takich danych. Komentarz, red. P. Litwiński, P. Barta, M. Kawecki, Warszawa 2018.

Ławrynowicz-Mikłaszewicz M., Bezpieczeństwo jako prawo człowieka w kontekście stosowania środków przymusu bezpośredniego i broni palnej przez uprawnione podmioty, „Przegląd Prawniczy, Ekonomiczny i Społeczny" 2014, nr 4.

Masternak-Kubiak M., Przestrzeganie prawa międzynarodowego w świetle Konstytucji Rzeczypospolitej Polskiej, Wrocław 2003.

Mednis A., Reforma europejskich regulacji prawnych dotyczacych ochrony danych osobowych - najważniejsze kierunki proponowanych zmian, „Informacja w Administracji Publicznej” 2015, nr 1.

Mielnik Z., Prawo do prywatności (zagadnienia wybrane), „Ruch Prawniczy, Ekonomiczny i Socjologiczny" 1996, nr 2. 
Privacy Rights in the Digital Age A Proposal for a New General Comment on the Right to Privacy under Article 17 of the International Covenant on Civil and Political Rights: A Draft Report and General Comment by the American Civil Liberties Union, https://www.aclu.org/sites/default/files/assets/jus14-report-iccpr-web-rel1.pdf.

Safjan M., Prawo do prywatności i ochrona danych osobowych w społeczeństwie informatycznym, „Państwo i Prawo” 2002, nr 6.

Sakowska-Baryła M., Dostęp do informacji publicznej a ochrona danych osobowych, Wrocław 2014.

Sarnacki P., Komentarz do art. 47 Konstytucji, [w:] Konstytucja Rzeczpospolitej Polskiej. Komentarz, t. 2, red. L. Garlicki, M. Zubik, Warszawa 2016.

Siostrzonek-Sergiel A., Prawo do prywatności a bezpieczeństwo publiczne realizowane przez proces karny, „Kultura Bezpieczeństwa. Nauka — Praktyka — Refleksje” 16, 2014.

Wild M., Komentarz do art. 47 Konstytucji, [w:] Konstytucja RP. Komentarz, t. 1, red. M. Safjan, L. Bosek, Warszawa 2016.

Wójtowicz K., Komentarz do art. 9 Konstytucji, [w:] Konstytucja RP. Komentarz, t. 1, red. M. Safjan, L. Bosek, Warszawa 2016. 